\title{
FRAGMENTO / POLÍTICA / REPRESENTACIÓN: CONTACTOS (1970) DE PAULINO VIOTA ${ }^{1}$
}

Rubén García López

Universidad de Valparaíso

Data Recepción: 2019-04-23

Data Aceptación: 2020-04-08

Contacto autor: ruben.garcia@uv.cl

ORCID: https://orcid.org/0000-0001-9266-5699

\section{RESUMEN}

Pieza clave del cine independiente español del tardofranquismo, Contactos es uno de los filmes españoles más rigurosos en su articulación de las relaciones entre forma cinematográfica e ideología, entendidas desde un punto de vista acorde con el materialismo propugnado por los Cahiers du Cinéma de la época. Se considera aquí esta relación, así como la también existente con el pensamiento del escultor Jorge Oteiza, atendiendo principalmente a los elementos que separan el filme de Paulino Viota de los mismos. Principalmente, para ello se recurrirá tanto a las reflexiones de Raúl Ruiz sobre la dialéctica fascinación/distanciamiento, así como al análisis de la otra dialéctica existente en el film entre fragmento y sinécdoque, central para la comprensión de un dispositivo que se comprende al mismo tiempo como ruptura de la representación y como representación ideológicamente determinada, inmersión tan sensorial como intelectual que logra evidenciar en sus mecanismos las prohibiciones políticas de tipo estético que determinaban profundamente la producción cinematográfica del periodo.

Palabras clave: política, representación, fragmento, sinécdoque, Paulino Viota

\section{ABSTRACT}

A seminal work in independent Spanish cinema of the late Franco years, Contactos is one of the most rigorous Spanish films in articulating the relations between ideology and cinematic form, understood in terms of the aesthetic and political materialism of the Cahiers du Cinéma of the time. That relationship is considered here, in addition to links with the thinking of the sculptor Jorge Oteiza, with the main focus being on the aspects that make Viota's film differ from these points of reference. Raúl Ruiz's thoughts on the dialectics between fascination and distancing are considered and an analysis provided of the film's other dialectics between fragment and synecdoche. This is a topic central to the understanding of a film that is, at the same time, a fracture of representation and an ideologically determined representation, an immersion as sensorial as it is intellectual, which reveals in its formal mechanisms political prohibitions of an aesthetic nature that profoundly influenced cinematic production of the period.

Keywords: politics, representation, fragment, synecdoche, Paulino Viota

Contactos, largometraje realizado en 1970 por un joven de 22 años llamado Paulino Viota, constituye uno de los hitos del cine independiente español, el nombre que algunos críticos a finales de los sesenta (Molina Foix 1968, 72-76) dieron a la producción cinematográfica de varios cineastas, realizada con frecuencia sin permiso o financiación estatal e incluso sin existencia legal, a lo largo 


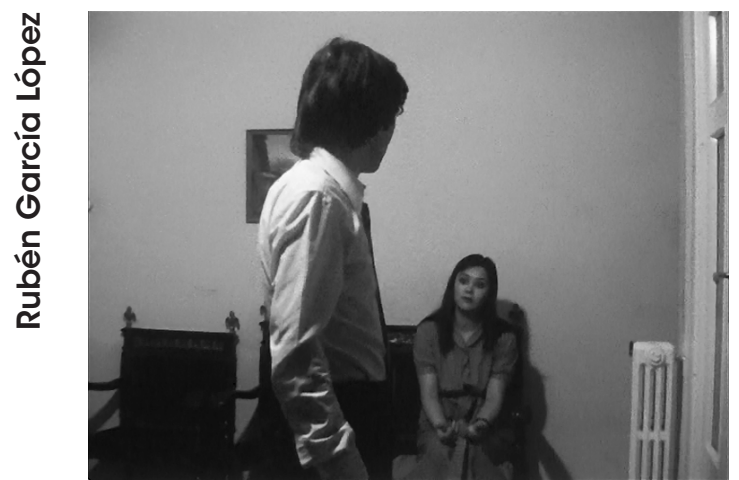

Fig. 1. Viota, Paulino, Contactos, 1970.64'

de la última década de existencia del franquismo, habitualmente en formatos subestándar². Aunque tradicionalmente este cine se haya visto muy minusvalorado por lo que Marta Hernández denominará "el aparato cinematográfico español" (Hernández 1976), en los últimos tiempos ha habido una reivindicación decidida de algunos de sus títulos, principalmente largometrajes que constituyen piezas clave de la cinematografía española más arriesgada y experimental, como ... ere erera baleibu izik subua aruaren (José Antonio Sistiaga, 1968-1970), Umbracle (Pere Portabella, 1972), La celosía (Isidoro Valcárcel Medina, 1972), o la propia Contactos, incluida junto a los filmes de Portabella y Sistiaga entre las cien mejores películas españolas por una reciente votación de la revista Caimán $n^{3}$. Fue asimismo una de las obras escogidas por la fundamental Antología crítica del cine español 1906-1995 (Pena 1997, $677-$ 679), y es rara la historia del cine español que no la considere aunque sea de pasada, siendo además reconocida por algunos autores extranjeros como Noël Burch o Pierre Léon (Léon 2014)4. En la última década, fue restaurada gracias a una colaboración entre la Filmoteca Española y el Museo Nacional Centro de Arte Reina Sofía, proyectándose en festivales como el FID Marseille, la Viennale o Punto de Vista en Navarra, amén del Jeu de Paume en París, el Lincoln Center de New York, el Círculo de Bellas Artes madrileño o la Filmoteca de Santander, ciudad natal del realizador, siendo además editada en DVD junto a la restante filmografía de Viota5, asimismo objeto de un libro colectivo reciente (García López 2015).

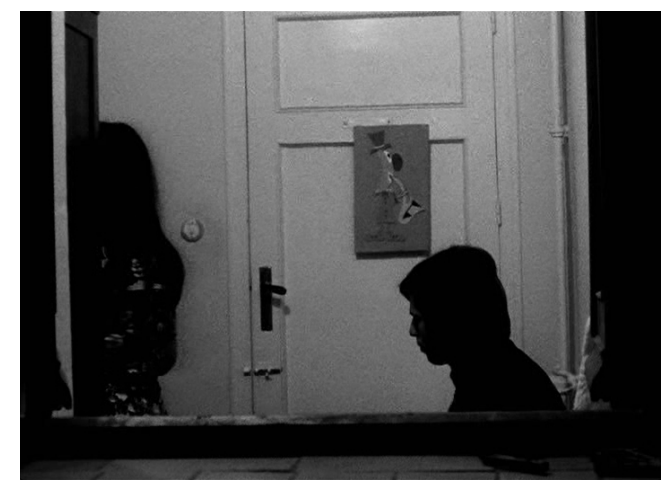

Fig. 2. Viota, Paulino, Contactos, 1970. 64'

La gran singularidad de Contactos procede de su enorme coherencia entre sus planteamientos económicos, ideológicos y formales, una propuesta muy poco habitual en el contexto del cine español, e incluso internacional, del periodo. Contactos es un peculiar filme político y su comprensión precisa tanto analizar su relación con su contexto social como el modo en que su articulación formal pretende ser un elemento en sí mismo ideológico, planteamiento estético que también encuentra su fundamento en elementos como el auge del pensamiento marxista en Europa y su vinculación en los años sesenta al estructuralismo, la semiótica y la crítica cinematográfica francesas.

\section{Génesis}

Contactos se rueda en mayo de 1970, aunque se desconocen las fechas exactas y el número de sesiones de rodaje, presumiblemente escasas. Fue realizada clandestinamente sin pedir cartón de rodaje y filmada en $16 \mathrm{~mm}$, partiendo de un presupuesto inicial de 25000 pesetas aportadas por la madre de Viota, escasez presupuestaria que no permitió el uso de travellings para los desplazamientos de la cámara, realizados con silla de ruedas en los exteriores y a pie, cámara en mano, en los interiores ${ }^{6}$.

El copión de Contactos fue montado por Viota y Guadalupe G. Güemes, actriz protagonista del filme, alumna de interpretación de la Escuela Oficial de Cinematografía (EOC) y pareja del cineasta ${ }^{7}$, en junio, en una visionadora sin motor propiedad de Juan Tamariz, alumno de dirección 
de la EOC por aquel entonces, antes de comenzar, poco antes del 24 del mismo mes el trabajo de doblaje y sonorización en una tienda llamada CEHASA ${ }^{8}$. Viota, Güemes y el técnico de la tienda harán todos los trabajos incluyendo el montaje del negativo, labor que solía realizarse en los laboratorios pero que, por la escasa cantidad de planos a montar, se decide ejecutar en la tienda, que ofrece un precio mucho más asequible ${ }^{9}$. La primera copia se proyectó de forma privada en torno a finales de octubre en CEHASA, con público externo en al menos una ocasión: como mínimo Francisco Llinás, Julio Pérez Perucha, Emilio Martínez Lázaro y Augusto Martínez Torres, los dos primeros críticos de la revista Nuestro Cine que en la década siguiente serían figuras centrales del Nuevo Frente Crítico, el colectivo Marta Hernández y la revista Contracampo (López Sangüesa 2019, 5-93), y los siguientes figuras conocidas del cortometraje independiente madrileño. El estreno público tendría lugar al mes siguiente,

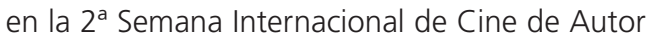
de Benalmádena, proyección sobre la que escribirá Llinás en el que acabó siendo último número de Nuestro Cine (Llinás 1971) ${ }^{10}$.

Para entender no obstante la singularidad de Contactos, es más útil considerar su proceso de escritura. Esta comienza a inicios de 1969, siendo escrito el primer borrador, titulado "Síntesis" (en adelante (1), por Javier Vega, primo de Viota y colaborador en José Luis y Fin de un invierno. En ese momento, $\mathrm{C} 1$ es una película compuesta por como mínimo ocho planos-secuencia de diez minutos de duración"1, y ya cuenta la misma historia de Contactos: una joven (Tina) llega a Madrid, se instala en una pensión y empieza a trabajar de camarera, tras lo cual inicia una relación con otro inquilino de la misma pensión (Javier), militante antifranquista al que incorpora a su mismo trabajo, al tiempo que se prostituye con un cliente del restaurante. El uso del plano-secuencia sí difiere grandemente del que acabará caracterizando a la película: la cámara tiene una gran movilidad y cada plano reúne escenarios de diversa índole, generalmente explorados a fondo: así por ejemplo un plano puede empezar en la calle, entrar a un edificio, luego a una casa y finalmente a alguna habitación, o en un restaurante explorar cocina, mostrador, comedor, lavabo, etc., utili- zando para ello todas las escalas de planos, desde generales a detalles.

El desarrollo de C 1 continúa a lo largo del año, pero termina estancándose en verano. Vega escribe otro borrador con un planteamiento distinto, en el que entre otras cosas los planos-secuencia dejan de ser imperativamente de diez minutos e incluso se abandona su uso en algunos momentos, al tiempo que el empleo de la elipsis se radicaliza, con grandes cambios argumentales entre secuencias que buscan la confusión del espectador. Esta propuesta empero no prospera, de manera que el giro fundamental llegará por la aportación de Santos Zunzunegui, que bajo el título "Cinema" (C2) reúne varias escenas, planos-secuencia de duraciones diversas si bien predominantemente breves, que recogen pequeñas acciones o gestos, y a las que se suman algunas otras de José Ángel Rebolledo, pensadas todas para ser alternadas con lo ya existente ${ }^{12}$. La concepción del plano-secuencia se reafirma en la voluntad de constreñir su omnipotencia habitual: al estar cada secuencia compuesta por una única toma, sin otras en consecuencia para recoger lo que queda fuera de campo, el off cobra un gran protagonismo, y los tiempos muertos y hechos enigmáticos se potencian. Esta era una tendencia que ya se había ido haciendo presente en el desarrollo de C1, pero la nueva aportación radicaliza la propuesta estableciendo con rotundidad la fragmentación como constante formal del filme.

En efecto, en el diseño de movimientos de cámara y puesta en escena elaborados por Viota a partir de C1 se tendía en algunas ocasiones a reducir o dejar en fueracampo la gran cantidad de elementos aportados por el guión. Desde el primer momento interesa a Viota el espacio vacío y la potenciación del espacio off, pero en aquella fase parecen deberse a la idea de que es imposible que en la filmación de una realidad determinada durante diez minutos todo sea interesante. La radical articulación de que serán objeto en Contactos no se planteará decididamente hasta la entrada de Zunzunegui en el proyecto y, finalmente, hasta la decisión de filmar los interiores aprovechando sus patios y ventanas, la cual sin duda, por coherencia formal, afectó al modo de filmar los restantes escenarios e incluso reducir su número. 


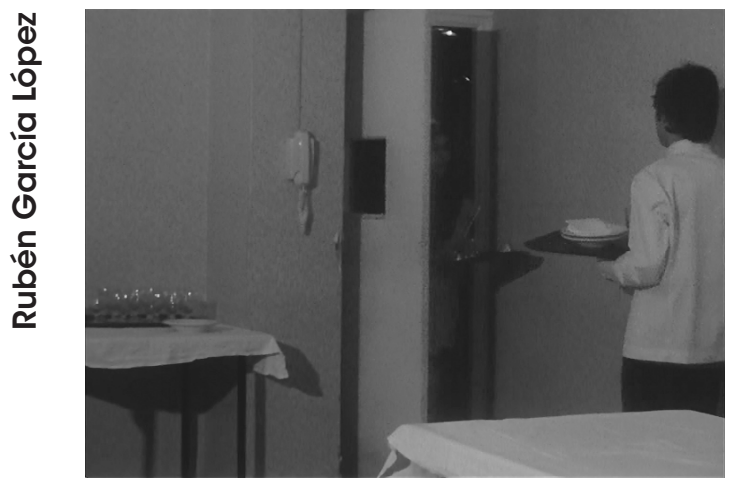

Fig. 3. Viota, Paulino, Contactos, 1970. 64'

En el guión final (C3), elaborado por Viota aproximadamente en abril de 1970 (Vega, Zunzunegui y Viota 2015, 335-392)'ª la cámara todavía sigue a los personajes, recorre pasillos, entra en habitaciones, se aleja o acerca a los personajes, etc., mientras en Contactos solo se desplazará de forma lateral, manteniéndose a una distancia prudencial de los actores, muy a menudo encuadrados en plano medio, americano o general ${ }^{14}$ (fig. 1). Las dos casas utilizadas permiten el rodaje de los interiores desde un patio facilitando con ello los citados desplazamientos laterales, pero también que durante estos se pierda de vista a los personajes, cubiertos completa o parcialmente por marcos o tabiques (fig. 2). Este planteamiento se hará extensivo a los otros dos escenarios: los diversos exteriores presentes en C 3 se reúnen en uno solo, pero dividido en tres zonas cuya unidad tardará en establecerse, y el restaurante pasa a ser el único escenario filmado siempre del mismo modo, con un plano fijo que registra un trozo de pared y una puerta batiente que da paso al comedor (fig. 3).

Con esto, el trabajo de cámara y montaje adquiere una radicalidad inesperada, al repetirse además idénticas posiciones y encuadres y ser imposible el seguimiento más allá de puertas y paredes. La brutalidad de las elipsis, que deja sin conocer rasgos fundamentales de la trama, perdidos en una distancia entre secuencias siempre imposible de determinar, se ve replicado por el doble ejercicio del fueracampo: el exterior a los bordes del encuadre y el interior, generado por los límites espaciales. El contexto físico se impone: cuando un personaje entra en su habitación no hay montaje que permita el corte a su interior, de modo que el encuadre se sostiene hasta que el personaje reaparezca, dejando al espectador entretanto ante la visión de un pasillo vacío. De esa manera, los momentos faltos de presencia humana serán numerosos, y lo que se hace allá donde la mirada no alcanza, secreto, muchas veces imposible de saber ${ }^{15}$. Si el cine llamado "clásico" de Hollywood (aunque no solo él) tenía la tendencia a "representar la omnisciencia narrativa como omnipresencia espacial" (Bordwell 1996, 161), de modo que la cámara ostentaba el poder de registrar el lugar que quisiera cuando quisiera, colocando al espectador siempre en la mejor posición posible para presenciar los acontecimientos en cuestión, Viota elimina tal omnisciencia reduciendo los espacios, la movilidad de la cámara y la amplitud de la mirada, muy a menudo acotada por marcos diversos (de puertas, ventanas o pasillos) en manifiesta acción de reencuadre ${ }^{16}$.

\section{El anti-Oteiza}

A cada reescritura del guión, en consecuencia, la cantidad de información disponible para el espectador se había visto reducida, culminando en una película donde la mayoría de hechos fundamentales tienen lugar fuera de campo y las repeticiones, reiteraciones y redundancias no ya narrativas sino también formales tienen el efecto de acabar llamando la atención sobre la propia formalización de la película, de un modo que el propio Viota (y con él muchos comentaristas posteriores) explicaría mediante la influencia de una de las referencias fundamentales del filme, el escultor vasco Jorge Oteiza.

En Quosque Tandem...!, Oteiza explica una idea que nos conmocionó a Santos y a mí profundamente: la de que bastan tres golpes para extraer lo figurativo de un bloque de madera. Esta era una idea que estaba muy ligada a esa búsqueda de que la forma sea perceptible, visible. Hay un ejemplo concreto en la obra de Oteiza, la figura de un rostro humano, en concreto de un apóstol, que hizo para una iglesia en el País Vasco. La idea era que cogía un trozo de madera $y$, dándole sólo tres golpes, de una determinada manera, conseguía sugerir la cabeza de una persona. De este modo también quedan muy visibles los tres golpes del martillo, del instrumento. Es decir, el elemento formal, al ser muy sencillo, no 
desaparece, queda evidenciado. Y eso, tal cual, es Contactos (Adell 2011) ${ }^{17}$.

Tres golpes en Oteiza, treinta y tres planossecuencia en Viota, de duraciones muy diversas, de diez minutos a cuatro segundos, cortando pedazos de tiempo de las vidas de sus protagonistas, a veces útiles para entender su situación, otras absolutamente irrelevantes, otras aparentando cierta imprecisa importancia. Al igual que las paredes y puertas bloquean nuestro deseo de saber qué pasa al otro lado, el trabajo formal de Contactos se experimenta en ocasiones como un obstáculo para la comprensión de lo que sucede. Antes que la potencia del plano-secuencia y del montaje, interesa a Viota la forma en que nunca pueden no dejar algo de lado. Su impotencia.

Es en este punto que podemos empezar a intentar entender la dimensión política de Contactos, que podría introducirse por la comparación con la propia obra de Oteiza y sus planteamientos teóricos. Con su autodenominada "ley de los cambios", Oteiza había aportado una idea que, aunada al interés por las obras de pintores como Malévich o Mondrian, prendió con intensidad en Viota y Zunzunegui. Según el vasco, el arte comenzaría por una primera fase que partiría de un cero en busca de una ocupación del espacio, un acto de expresión y comunicación que se vería progresivamente sucedido por una segunda fase basada ahora en la desocupación del espacio, donde el arte deja de ser expresión y donde si antes "consideraba una nada como punto de partida, considera [ahora] una nada como punto de llegada" (Oteiza 1994, 72) ${ }^{18}$.

Para Oteiza, el arte debía seguir este proceso de vaciamiento expresivo, esta "estética negativa" 19 que en efecto coincide con la de Contactos, con su simplificación de movimientos de cámara, reducción de espacios y limitación del acceso a los mismos, sofocamiento de la gestualidad física y entonación verbal, con su ausencia de color y contados sonidos, con todo el trabajo en suma que en la película hay de reducción de elementos. Ahora bien, el apagamiento expresivo en Oteiza tenía un destino: hacer desaparecer el arte para generar un hombre. El fin del arte servía para crear un pueblo, gestado en ese espacio vacío abierto para acogerle, para crear en él el final del miedo a la muerte, ese sentimiento

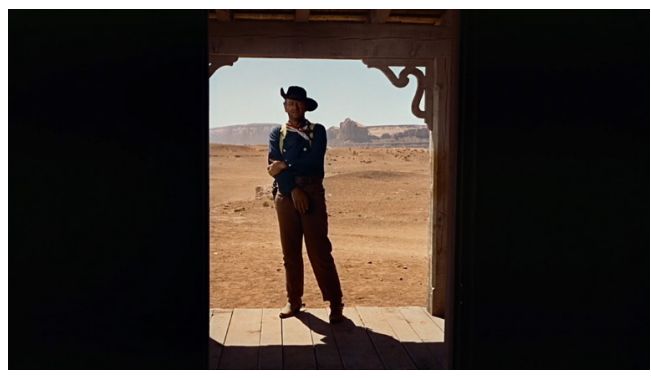

Fig. 4. Ford, John, The Searchers [título de la versión en español, Centauros del desierto], 1956. 119'

trágico de la vida que, para Oteiza como para Unamuno, atenaza al hombre impidiéndole una vida plena, y crear por ello al fin un alma, el alma de un pueblo. La teoría artística de Oteiza no busca sino una solución para el problema unamuniano y una explicación del alma vasca. En el apagamiento expresivo, lo que hay es un hombre que empieza a habitar poco a poco el vacío, un vacío acogedor, protector, que hace al hombre vivirse a sí mismo y no sentir ya la necesidad de la expresión, en realidad una necesidad del miedo más que de la vida (Oteiza 1994, 75-78). El vacío de las cajas metafísicas de Oteiza está hecho para el hombre, para acogerle, para protegerle, es un vacío que abre en su espíritu un espacio de protección, le convierte en hogar de sí mismo, le da propiamente un alma. Como los pasillos de Yasujiro Ozu o los marcos de John Ford (otras dos referencias de Viota), reconoce la angustia, pero para darle cobijo.

El vacío de los planos de Contactos no es acogedor. La puerta que enmarca a Ethan Edwards en el célebre plano final de The searchers (John Ford, 1956) (fig. 4) remarca su permanencia en el afuera de la comunidad, pero también permite reconocer y con ello abrazar esa soledad, llamar nuestra atención sobre ella, es decir atender y mirar aquello que la comunidad olvida. Igualmente los espacios en Ozu, de una gran autonomía, puntúan y pautan la vida de sus ocupantes, introducen un equilibrio que muchas veces está ausente de sus existencias. Los reencuadres de Ozu rescatan una armonía y aseguran un acogimiento, algo que de ningún modo harán los de Viota. Los planos de Contactos cercenan sistemáticamente el poder y libertad del espectador y en la periferia de sus encuadres solo podemos 
encontrar espacios grises e inhóspitos. Contactos es una máquina de angustia, cuyo vacío no está hecho para ser habitado sino para habitar, para inundar el corazón de los que viven en él y llegar a quienes lo contemplan. El vacío de Oteiza es un vacío donde se gesta un alma, el de Contactos es el vacío donde este alma se aplasta, no propiamente un vacío sino una forma que dirige y aboca hacia él, no ya un vaciamiento del espacio o de la forma sino, a través de estos, de los individuos que lo habitan. Contactos es la expresión de esa destrucción de todo lo vivo, la muerte de verdad trabajando, no el fin del miedo a la muerte sino el ejercicio libre y pleno de su acción, el registro de su obra. Por ello años más tarde, Viota reflexionaría que "Contactos es Crónica de Anna Magdalena Bach (Chronik der Anna Magdalena Bach, Danièle Huillet, Jean-Marie Straub, 1968) sin Bach, sustituyendo la música genial del cantor por la atmósfera oprimente del franquismo; sustituyendo el placer incesante de la escucha de la película de Straub, por la rutina opresiva de la vida bajo Franco" (Viota 1998, 112).

\section{Una película marxista}

Tras la realización de Contactos, Viota y Zunzunegui, con la ocasional ayuda de otros amigos, escribieron una serie de textos para acompañar las proyecciones del filme. Todos ellos insisten en la explicación de su dispositivo fílmico como uno destinado a explicitar los mecanismos de producción del discurso cinematográfico y, más aún, a romper con la alienación de la ilusión cinematográfica. Con ello, los autores se situaban inequívocamente en sintonía con el cine y la crítica materialista defendidos en aquel entonces por la revista Cahiers du Cinéma, que a partir de 1963 había empezado a pensarse como "instrumento de combate" (Anónimo 1963, 1) y abierto a líneas teóricas hasta entonces poco presentes en sus páginas: el marxismo, el psicoanálisis, la semiótica y el estructuralismo. Althusser, Lacan, Barthes o Lèvi-Strauss se habían convertido en referencias fundamentales para el sector más trascendental de la crítica francesa, y en su mayoría llegarán también a Viota y Zunzunegui, lectores fieles de la revista20, cuya voluntad de aunar reflexión formal e ideológica suponía la posibilidad de superar el debate entre cinefilia y contenidismo que ca- racterizó la larga polémica entre las revistas españolas Film Ideal y Nuestro Cine durante los años sesenta. Como muchos cinéfilos de la década, la ideología antifranquista y crecientemente marxista de los dos amigos les acercaba a la segunda, pero el cine que más apreciaban era el defendido por la primera, que además prestaba una mayor atención a las formas cinematográficas, mucho más preocupada la otra por la idoneidad de su dimensión discursiva. La nueva crítica cahierista permitía establecer vínculos directos entre forma e ideología, de manera que la reflexión sobre la primera no quedaba en un mero plano estético y la segunda en otro discursivo, generando una suerte de programa para, desde la primera, poder intervenir en la segunda.

Un texto fundamental en este programa materialista, de clara raigambre althusseriana, lo constituye el célebre "Cinéma / idéologie / critique", escrito por Jean-Louis Comolli y Jean Narboni en 1969, donde se categorizan los diversos modos de relación entre cine e ideología, dando sitio tanto a John Ford como a lo que será Contactos, fácilmente ubicable en la categoría $B$, que define a los filmes políticos al nivel tanto de los significados, mediante un "tratamiento explícitamente político de uno u otro tema", como de los significantes mediante una "deconstrucción crítica del sistema de representación", y configurándose por lo tanto como la única categoría que a juicio de los autores tendría "alguna oportunidad de ser operativa contra (en) la ideología dominante" (Comolli y Narboni 2008, 79)21. Contactos en efecto tendrá un tratamiento político de su tema (al menos dos personajes son militantes antifranquistas, posiblemente comunistas, y las penurias de la condición obrera son el determinante fundamental de la pareja protagonista), pero también planteará una labor política a nivel formal. Inspirados en la afirmación de Mao de que en las concepciones sobre el desarrollo del universo existían dos concepciones enfrentadas, la metafísica y la dialéctica (Zedong 1976, 334)22, la cinefilia materialista establecerá un enfrentamiento entre idealismo y materialismo estéticos cuyo gran nombre va a ser el de Bertolt Brecht, para el cual, según Barthes, el arte debía ser una "anti-Physis", una lucha contra "la falsa Naturaleza burguesa y pequeñoburguesa: en una sociedad aún alienada, el arte debe ser crítico, 
debe cortar toda ilusión, incluso la de la "Naturaleza"» (Barthes 2009, 114). Tal como afirmará Marta Hernández, «la confusión entre el signo (la llamada "imagen") y la realidad significada (lo "representado" por esa "imagen")» (Hernández 2016 , 49) será en consecuencia entendida como la característica esencial del idealismo estético, y aquello contra lo que debían luchar el cine y crítica materialistas.

La estrategia de Viota presenta notables diferencias respecto a los cineastas citados (a los que podría sumarse el Godard de la época, entonces en el Grupo Dziga Vertov), ya que el distanciamiento de Contactos no solo no va en detrimento de su dimensión emocional sino que, muy al contrario, busca una inmersión absoluta en el inhóspito universo que representa. Dicho de otra manera, los procedimientos distanciadores de Contactos son la condición de la inmersión en la película, los pilares de sus mecanismos representacionales. Para entender este proceso, puede ser útil recordar estas palabras (muchas décadas posteriores) de Raúl Ruiz:

[el distanciamiento] es indispensable no sólo para captar racionalmente una película (...) sino también para vivir los hechos de la película en toda su complejidad. No olvidemos que vivir una obra de arte no consiste sólo en estar fascinado por ella, en enamorarse de ella, sino también en comprender el proceso del enamorarse. Para eso necesitamos la libertad de alejarnos del ser amado, cosa de volver mejor a él, libremente. El encuentro amoroso con una obra de arte es una práctica erótica que se resume en esta fórmula: amar te hace inteligente-lo que contradice aquella según la cual el amor aturde como un bastonazo en la cabeza (Ruiz 2013, 187)23.

Por supuesto, el propio Ruiz es consciente de lo poco que esto tiene que ver con los planteamientos brechtianos:

En Brecht, el pathos formal de la obra requiere un alejamiento para facilitar el pasaje al acto (político). En el proceso que estamos describiendo, el pasaje al acto (político) sobreviene en el interior del campo abierto por la obra de arte misma. Es la obra, no el espectador, la que pasa a la acción, la que se extiende, invade el mundo que rodea al enamorado y, por así decirlo, lo colorea, lo tiñe (Ruiz 2013, 187188).
La idea de Ruiz es luminosa para entender por qué, utilizando todas las herramientas distanciadoras y descentradoras posibles, se genera aquí lo contrario a un distanciamiento emocional, antes bien una adhesión doliente, una participación donde la angustia de las imágenes domina con rotundidad el espectáculo. Esto se da no a pesar, sino gracias al distanciamiento. En Contactos la consciencia de la formalización agrava la angustia, tanto por la pobre factura visual que potencia la grisura de los ambientes como porque su presencia se manifiesta en tanto violencia constante, incluso arbitraria en muchos momentos en que la cámara se desplaza sin seguir a nadie o, al contrario, decide no moverse cuando ello convendría para corregir un encuadre o no perder de vista a un personaje. Ciertamente, es difícil hablar de "fascinación" como lo hace Ruiz, pero esta debiera entenderse en el sentido de inmersión en el mundo propuesto por la obra, y si tal es un universo angustioso y terrible, pocos juicios más acertados cabe hacer sobre Contactos que el que resultaría de parafrasear al chileno afirmando que es la película "la que pasa a la acción", la que "invade el mundo que rodea" al espectador, "lo colorea, lo tiñe", pero en los colores menos vivos posibles. Dicho de otro modo, el espectador, más que vivir, es vivido por la obra o, dicho de otro modo, la padece.

Contactos es una película marxista, pero sumamente peculiar. En ella importa más que la lucha antifranquista la alienación del trabajo, de muchas horas, mal pagado y en malas condiciones, siendo habituales las referencias a cómo desgasta a quienes lo viven impidiéndoles apenas hacer nada más con sus vidas. Sin embargo, a pesar de la evidente voluntad de denuncia, Viota no se extiende describiendo estas condiciones de trabajo; simplemente, muestra la puerta de una cocina y cómo entran y salen por ella los camareros y camareras, entrando comida y trayendo platos (fig. 3). Viota intenta un movimiento radicalmente contrario al habitual en el cine político de su credo: en vez de especificar las condiciones socio-económicas de una situación determinada muestra la situación abstrayéndola precisamente de todo aquello que podría permitirle construir un discurso (político) sobre ella. Del trabajo de los protagonistas, tan importante en la película, Viota solo muestra un encuadre, siempre el mismo, en momentos distin- 


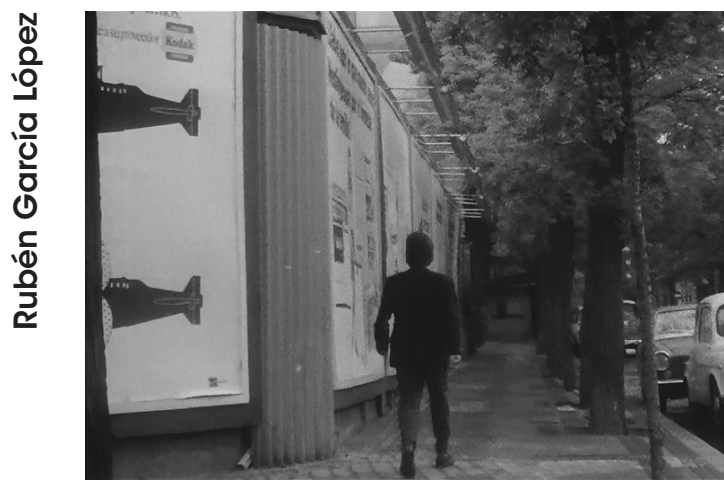

Fig. 5. Viota, Paulino, Contactos, 1970. 64'

tos a lo largo de todo su metraje. No se extiende más, no muestra jefes, capataces crueles, nada: solo el constante entrar y salir durante un tiempo que se hace interminable ${ }^{24}$. Afirma, sobre todo, el lugar y sus reglas, que dominan el tiempo de los cuerpos, dominio que afecta a estos incluso en el afuera de su espacio específico. Que algunos de los protagonistas pertenezcan a cédulas de resistencia anti-franquista es importante entre otras cosas por mostrar hasta qué punto incluso esta dimensión se ve afectada por la otra. Cuando un personaje llega a su habitación y se queja por las horas de trabajo, y manifiesta su agotamiento y habla de la necesidad de vacaciones, o de jornadas de ocho horas, esa pesadez se entiende porque se ha visto y ve, porque es, de hecho, lo único que se ve, porque el tiempo de las habitaciones o el de la calle es tan pesado como aquel. Se percibe en el movimiento lento, torpe y apesadumbrado de los cuerpos, en las palabras angustiadas y rendidas, y en el apoyo de esa textura que unifica toda la película, el grano asfixiante del 16 hinchado a 35mm. Todo en la película es coherente con lo único que los personajes llegan a manifestar explícitamente: las penurias de su trabajo.

\section{Poética del fragmento}

Comparemos, no obstante, cualquiera de los planos del restaurante con otro como aquel (acaso el más célebre de la película) en que Javier da la vuelta a la manzana mientras la cámara le espera y Juan, su contacto en el partido, cronometra su recorrido (figs. 5 a 7). Si bien, por la identidad de los dos hombres, asumimos que el acto tiene

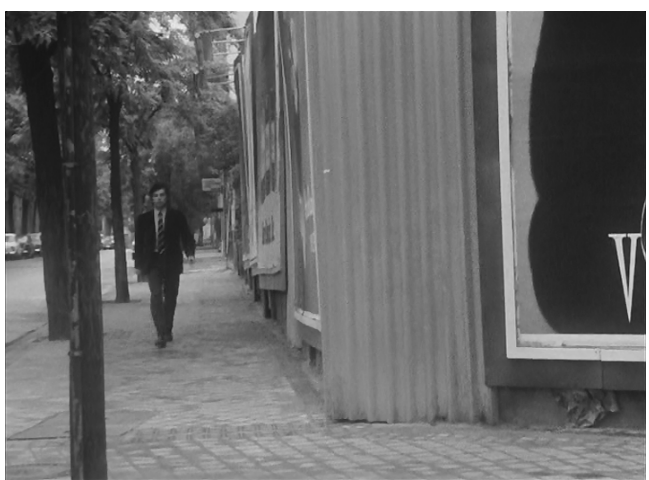

Fig. 6. Viota, Paulino, Contactos, 1970. 64'

algo que ver con su labor clandestina, ignoramos propiamente lo que hacen y, más aún, se impone el tiempo vacío de la calle, los segundos que se acumulan sin sentido. La cámara no presta siquiera atención al hombre que espera sino que se desplaza de un lado de la calle al otro, se detiene y también espera, como aquel pero no con él. En la misma posición, en otro momento, filmaba a Javier y Tina hablando con alguien, pero la lejanía era tal que nada de la conversación llegaba a nuestros oídos (fig. 8). Ambos planos duran tres minutos.

Roman Jakobson consideraba la sinécdoque como "el método fundamental para transformar en el cine las cosas en signos" (Jakobson 1976, 175). Pero no hay sinécdoque sin fragmentación. Contactos es una película hecha de fragmentos que tiende a parecer, al menos en una primera visión, el resultado de tomar al azar varios pedazos de la vida de cierta gente y colocarlos unos detrás de otros sin mucho cuidado (aunque no sea así). Al ver Contactos se tiene la impresión de que la película es el resultado de haber escrito una historia, puesto todo lo importante en el fueracampo y dejado a nuestros ojos solo lo irrelevante. Haber hecho la película de modo que en todo momento sea evidente que nos falta todo por conocer y entender, desde las vidas de los protagonistas a sus pensamientos. Contactos aparenta ser un vaciado por el cual el cine, de la realidad, solo ha dejado lo visible y, de lo visible, solo lo irrelevante, lo mediocre.

La potencia significativa de los planos del restaurante, no obstante, es innegable. Existe por tanto una tensión en Contactos entre el fragmento y la sinécdoque, fundamental para definir tan- 


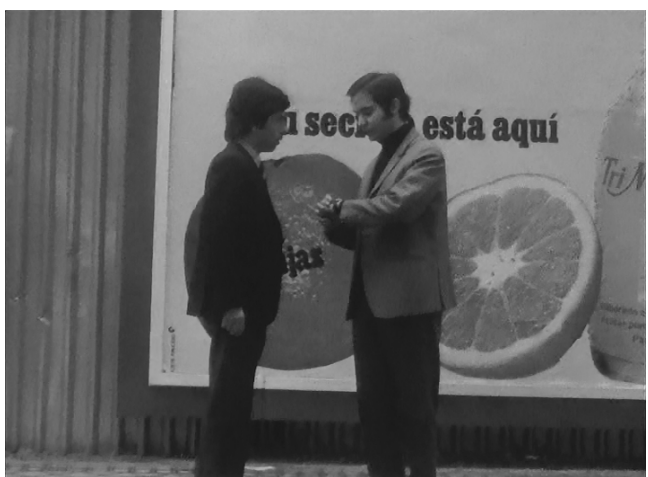

Fig. 7. Viota, Paulino, Contactos, 1970. 64'

to su dialéctica entre inmersión y distanciamiento como su pretendida dimensión política. El plano del restaurante representa el trabajo de camarero dotándolo de las características deseadas: el ir y venir tradicional de los camareros de un restaurante es convertido por mor de la duración y la atención concentrada (los camareros se mueven, la cámara no) en una suerte de tortura china donde salta a la vista la mecanización de los cuerpos humanos, sometidos a un monótono ir y venir que se asimila al de un objeto, la puerta que también va de un lado al otro, movida por una fuerza ajena. Nos encontramos con esto ante tal vez el más perfecto uso de la sinécdoque en todo el filme, una reducción de todo un complejo laboral a un trozo de espacio, que (re)percutirá con insistencia sobre toda la película, no solo por su repetición (frente a los restantes espacios, también la de un ritmo) sino porque es una imagen lo suficientemente sintética como para permitir que la referencia a ella sea automática cuando alguno de los personajes (sobremanera Javier) se queje de su trabajo. El procedimiento se asemeja mucho al que Jakobson ponía como ejemplo para afirmar la sinécdoque como herramienta principal del lenguaje cinematográfico:

Podemos designar a la misma persona diciendo: "el jorobado", "el narizotas" o "el jorobado narizotas". El objeto de nuestro discurso es el mismo en los tres casos, pero sus signos son diferentes. De la misma manera podemos, en un filme, tomar al mismo hombre de espaldas - se verá la joroba -, luego por delante será la nariz lo que será mostrado, o por fin de perfil, se le podrá ver la una y la otra. En estos tres planos, tenemos tres cosas que funcionan como los

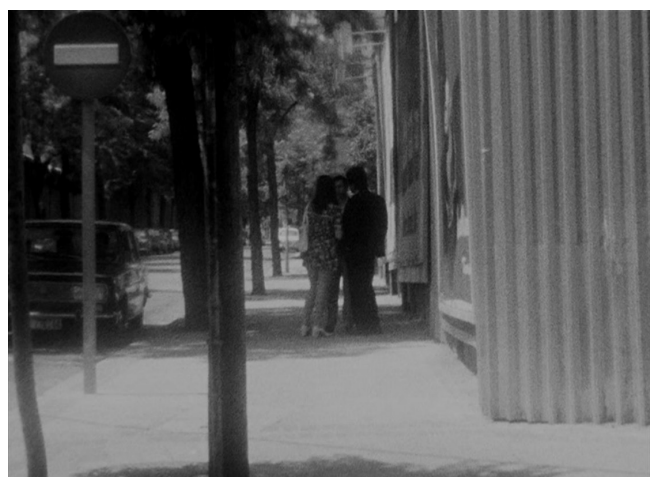

Fig. 8. Viota, Paulino, Contactos, 1970. 64

signos del mismo objeto. Desvelemos ahora el poder de la sinécdoque en la lengua y hablemos de nuestro monstruo diciendo simplemente "la joroba" o bien "la nariz". Procedimiento análogo en el cine: la cámara no ve más que la joroba, o bien más que la nariz. Pars pro toto: es el método fundamental para transformar en el cine las cosas en signos (Jakobson 1976, 175).

Si solo muestro de alguien su joroba, lo designo como jorobado. Del restaurante, Viota selecciona una sola parte para mostrar: así, el trabajo es caracterizado como una labor maquinal, repetitiva y monótona, donde la ausencia de cualquier otra consideración hace que toda referencia al trabajo lo sea a esa cualidad cuya reiteración hace esencial al concepto, perenne y unívoca.

La sinécdoque, pues, es la redención del fragmento, pues no es factible hablar de fragmento sin la conciencia de una quiebra, de un algo separado de algo, no hay fragmento si en la imagen de este no se da al tiempo un peso fuerte de aquello que no está. El fragmento es un campo sometido constantemente a una presión excesiva del fueracampo, angustiosa incluso. El fragmento en consecuencia bloquea la representación, la dificulta cuando menos, y esta tensión es esencial en la experiencia de Contactos.

\section{Política del fragmento: Filmar la pro- hibición}

Sobre una película como Sleep (Andy Warhol, 1963), Pasolini consideraba que la "carencia de significancia se siente tan rabiosa y dolorosamente que llega a herir al espectador y, con él, su idea del orden y su existencial amor humano por lo que 
existe" (Pasolini 1969, 65)25. Pero esa herida, que Pasolini postula en buena parte por la oposición europea al sensualismo y vitalismo norteamericanos de los sesenta, posee una enorme, si bien paradójica, pertinencia en el contexto de un cine hecho bajo dictadura. Pasolini opone el neorrealismo, que afirmaría que "lo que es significante, existe", al New American Cinema (NAC), que nos dice que "lo que existe, es significante" (Pasolini 1969, 65), teniendo esto como resultado, a su juicio, el triunfo de lo insignificante. Sin embargo, cabe aquí una tercera proposición: "lo insignificante existe, y es significante en tanto tal". ¿Significante en virtud de qué? En virtud de su vaciamiento casi absoluto de determinaciones, que posibilita su apertura a sentidos mucho más globales o abstractos. Allá donde Pasolini no puede concebir la creación del sentido más que a partir de cosas que ya lo posean en sí mismas, en el cine de Warhol, como en el de Jonas Mekas, la ausencia de significado genera signos con un sentido otro: signos de la vida entendida como ajena a la significación, vida celebrada o cuando menos atendida en su mero tener lugar, su carácter de evidencia ajena a ( $y$, a la vez, amiga de) casi todo lo que de ella pueda ser predicado. En Mekas, ideólogo de este tipo de signo, la flor, el gato o el café registrados durante apenas cinco fotogramas nerviosos se designan solo a sí mismos y por ello devienen en segundo grado signo de la vida, la naturaleza, la felicidad... Es porque se limitan a ser solo ellos que pasan a significar otra cosa sin necesidad de convertirse en metáforas o sinécdoques ${ }^{26}$.

En el ánimo político de Viota no existe problema en que sus tiempos muertos (y extensos), sus espacios vacíos o acciones secretas no generen ningún "amor humano por lo que existe", puesto que lo que existe es una dictadura, un sistema político que domina la casi totalidad de lo existente, inviste la realidad toda. Si los tiempos extensos y espacios vacíos generan desafección, será coherente con los sentimientos de sus protagonistas y con una realidad que no amerita afecto alguno; si lo insignificante se impone, esto será coherente con la imposibilidad de encontrar asideros vitales en un universo marcado por su desprecio hacia la dignidad humana. Si su película generara algún tipo de amor por lo que existe, ello redimiría en cierto grado una realidad infame, por lo que, si alguna calidez se manifiesta en Contactos, lo hará entre los personajes pero nunca entre estos, su mundo y su representación.

La sinécdoque pues, representa. Y el fragmento representa de otra manera: representa porque no representa, representa porque bloquea la representación, manteniéndose en un campo metonímico casi puro, apoyado en la potencia de su insistente redundancia. Aunadas ambas dimensiones, los pedazos de mundo mostrados representan una visión no solo de ese pedazo sino del conjunto, donde vemos que el universo que habitan estos jóvenes en el Madrid franquista de 1970 está marcado por el conservadurismo moral y unas inaceptables condiciones laborales, trabajos extenuantes, jornadas extensísimas y mal pagadas. Un mundo cuyo carácter irrespirable se ve favorecido en el plano sensorial por el formato visual, el grano hinchado, la insistencia en los tiempos muertos, los espacios vacíos, la parquedad interpretativa, etc.

Todo ello lleva a la desesperanza, la tristeza, la impotencia y el desánimo, el mismo que parece empujar al protagonista masculino a abandonar la militancia. Como ya se dijo, el vacío de Contactos aplasta el alma, y toda resistencia parece por tanto imposible. Si contra los abusos laborales y la dictadura existen formas específicas de lucha, no hay aquí llamadas a la batalla. Pero el gran hallazgo de Viota es haber encontrado el modo de manifestar las condiciones que imposibilitan tal clamor.

En Contactos sí hay militantes, y dado el contexto y ciertas pistas, muy posiblemente comunistas. Pero en la España de 1970 no se puede explicitar más. Una película no podía mostrar la lucha antifranquista, pero Contactos lo hará, de muy peculiar manera, no resignándose a no contar la historia prohibida pero sí aceptando las prohibiciones (políticas) de tipo estético. La respuesta a la desafección es la lucha, pero esta no puede mostrarse porque la dictadura lo impide; la solución de Viota será la operación, casi imposible, de mostrar esta lucha mostrando al mismo tiempo la imposibilidad de hacerlo. Mostrar sin mostrar, decir sin decir. Lo que el poder franquista quiere restar de sus calles, lo restará Contactos de sus imágenes pero evidenciando la resta, haciendo sentir lo obligado del silencio y generando por esa vía una estética y una narrativa precisa- 
mente fragmentadas, oprimidas y agujereadas, el ejercicio de dos conspiraciones: una, la de la resistencia, agazapada en lo invisible, escondida esperando el momento adecuado (que sabemos nunca llegó); otra, la del mundo franquista, que también quiere invisible a la resistencia y lo consigue porque es quien rige el negocio de lo visible (aunque su poder alcanza también a lo invisible, como ejemplifica la "secreta" aparición de la policía en la segunda secuencia).

Los fragmentos, a pesar de ser pedazos, no dejan en realidad ningún espacio libre entre ellos, ese supuesto vacío es en realidad lo que más lleno está. Es la naturaleza del fragmento, esa visibilidad torturada por el peso de lo invisible que le ha sido restado lo que posibilita que la película completa pueda verse como representación, en efecto, de una realidad constituida por miedos, sospechas, riesgos, extenuación, agotamiento y tristeza pero, sobre todo, verla en tanto constituida, es decir formada en base a prohibiciones y reglas que norman la realidad y su representación. Es la imposibilidad del fragmento para representar lo que le permite precisamente representar una realidad dominada por la voluntad absolutista del poder dictatorial. Podríamos para concluir incluso ver Contactos como un curioso film-denuncia: denuncia de todas esas películas que asumen las prohibiciones que les toca vivir pero no materialmente, esto es, sin hacer la prohibición perceptible en sus imágenes, sin hacer que esta percuta en la materialidad de su forma. Porque si tiene un enorme valor hacer visible lo prohibido, no lo tiene menos el hacer visible la prohibición. 


\section{NOTAS}

1 El presente trabajo forma parte del Proyecto Fondecyt Postdoctorado $n^{\circ}$ 3180086 .

2 Es el caso de los tres primeros cortos de Viota, Las ferias (1966), José Luis (1966) y Tiempo de busca (1967), rodados en Super 8, o Fin de un invierno (Viota, 1968), Duración (Viota, 1970) y Contactos, rodados en $16 \mathrm{~mm}$, si bien esta última se inflaría posteriormente a 35

3 Vid. Caimán n 49 (mayo 2016). La lista completa, con todas las películas votadas, puede consultarse en https:// www.caimanediciones.es/la-encuestacaiman-listado-completo/.

4 Burch, que vio Contactos en una proyección en la Cinémathèque parisina en verano de 1971, fue el primer autor extranjero en hacerse eco de su existencia, en términos siempre más que favorables. Las referencias al filme aparecen en al menos tres de sus libros y algún artículo.

5 Paulino Viota. Obras 19661982 (4 DVD's + libreto). Barcelona: Intermedio, 2014.

6 El coste del filme es incierto, pero los datos más firmes indican que el tiraje de la primera copia standard en $16 \mathrm{~mm}$ fue de 62.841 pesetas, convertidas en 139.424 con su ampliación a $35 \mathrm{~mm}$, realizada en enero de 1971 . La inversión inicial tuvo por tanto que ser aumentada, ahora ya por el padre de Viota, constructor perteneciente a la pequeña burguesía santanderina. Por supuesto, este dinero nunca fue recuperado.

7 Ingresó en la EOC en 1968, a sugerencia de Carlos Fernández Cuenca tras ver su trabajo en el estreno santanderino de Tiempo de busca.

8 El núcleo del trabajo se realizó entre el 24 de junio y el 7 de julio. El doblaje, concretamente, se realizó los días 25 a 27, de diez u once de la noche a cuatro o seis de la madrugada, para evitar los ruidos de la calle. Debe subrayarse que estos trabajos no se realizaron en un estudio sino en una tienda común, con medios por tanto precarios.

9 En consecuencia, los datos sobre la posproducción vigentes hasta ahora están equivocados. Durante mucho tiempo la versión oficial, establecida por Jaime Pena a partir de la información suministrada por el propio Viota en una carta de 1996 que sería publicada posteriormente (Viota 1998), afirmaba que el montaje fue realizado por Guadalupe G. Güemes junto a Gonzalo Álvarez, otro amigo santanderino que había editado el negativo de Fin de un invierno. Más adelante, Viota añadiría que habría tenido lugar sin su presencia, siguiendo instrucciones precisas, y finalmente, en algunas proyecciones de la versión restaurada, extendería esta ausencia a los trabajos de doblaje y sonorización. La información aquí presentada procede del estudio de facturas y albaranes, cotejo de firmas y entrevistas con los implicados.

${ }^{10}$ La película, pese a ser clandestina, sí pasó censura, requisito necesario para ser proyectada en el festival, siendo aprobada el 14 de noviembre con el siguiente comentario: "Película en $16 \mathrm{~mm}$. Parece ser experimental. Adolece de una auténtica falta de pericia. Sin problemas". Archivo General de la Administración, exp. 62419

${ }^{11}$ C1 nunca llegó a escribirse íntegro, pero sí existió un esquema global, hoy extraviado.

12 Zunzunegui y Rebolledo se hacen amigos de Viota durante la estancia de este en Bilbao, de 1965 a 1969. Rebolledo, que estudia dirección en la EOC, y que aporta dos secuencias a la película además de hacer labores de interpretación y doblaje, no constará como guionista en los créditos, pero sí de ayudante de dirección.

${ }^{13}$ En esta fase, la película no tiene título. Este llegará tras el rodaje, en algún momento de junio, inspirado por la obra Kontakte (1958-1960), del compositor Karlheinz Stockhausen (Ferrando García 2009, 398).

14 Para todo esto hay excepciones: hay dos primeros planos de Tina en la película, y dos movimientos de retroceso en la pensión, para pasar del salón al patio desde donde se filma la habitación de Javier. También existen panorámicas muy leves pero no por ello intrascendentes, como las que en la sexta secuencia concluyen con la desaparición de Tina del lugar donde se la suponía.
15 Según González Requena, el $22,69 \%$ de la película consiste en planos vacíos (González Requena 2015, 199).

16 De nuevo según Requena, el $44^{\prime} 64 \%$ de la película está ocupado por imágenes reencuadradas, como mínimo por un marco (González Requena 2015, 199).

17 Al margen, anotar que los golpes en realidad eran cinco

18 El ensayo de Oteiza carece de paginación convencional, a favor de una numeración temática, que es la aquí referida.

19 "Estética negativa, en cuyo término final de eliminaciones está la fantástica eliminación del propio lenguaje" (Oteiza 1994, 83).

${ }^{20} \mathrm{El}$ segundo refiere su lectura en común en Zunzunegui (2006, 9-10).

${ }^{21}$ La versión original del texto fue publicada en el número 216 de octubre de 1969 de Cahiers du Cinéma. Filmes de Kramer, Straub y Huillet o Glauber Rocha son algunos de los nombrados como ejemplos de la categoría.

22 Por supuesto, otros lo dijeron antes que él (como Lenin, al que cita), pero fue Mao la lectura central de aquel período para muchos.

${ }^{23}$ Los subrayados son del autor.

24 Había una jefa en $\mathbf{C}$, pero en las sucesivas reescrituras su presencia fue mermando hasta desaparecer.

25 Aunque sea irrelevante para la valoración de su tesis, debe hacerse constar que Pasolini habla más bien sobre la noticia que le habría llegado de Sleep, ya que ni la nombra directamente ni la describe bien.

26 Por supuesto, la apertura no es absoluta. Las imágenes de Mekas se encuentran determinadas por los parlamentos del autor, que generan una suerte de clave para la lectura de unas imágenes que no están hechas para ser "leídas" al modo de un libro o un filme narrativo común, sino de forma más próxima a la lectura musical (como cuando hablamos de tonalidades mayores o menores). Pero se trata de una determinación mínima y elemental, que en Contactos encuentra su paralelo en las escasas referencias explícitas a la dureza del trabajo. 


\section{REFERENCIAS}

Adell, María. "Con tres golpes. Fragmentos de una conversación con Paulino Viota." Contrapicado, Octubre 13, 2011. http://contrapicado.net/article/2-con-tres-golpes-fragmentosde-una-conversacion-con-paulino-viota/.

Anónimo. "Editorial." Cahiers du Cinéma 145 (Julio 1963): 1.

Barthes, Roland. Ensayos críticos. Barcelona: Seix Barral, 2009.

Bordwell, David. La narración en el cine de ficción. Barcelona: Paidós, 1996.

Comolli, Jean-Louis y Jean Narboni. "Cinéma / idéologie / critique." Cahiers du Cinéma 216 (Octubre 1969): 11-15.

Ferrando García, Pablo. "Contactos. Una poética del vacío." En Olas rotas. El cine español de los sesenta y las rupturas de la modernidad, 391403. Madrid: AEHC, Ediciones del Imán, 2009.

García López, Rubén, ed. Paulino Viota. El orden del laberinto. Santander: Shangrila, 2015.

García López, Rubén. "Paulino Viota. Vanguardia y retaguardia del cine español." Tesis Doctoral, Universidad Carlos III, Madrid, 2017.

González Requena, Jesús. "Contactos. Análisis textual de una enunciación enunciada." En Paulino Viota. El orden del laberinto, editado por Rubén García López, 108-200. Santander: Shangrila, 2015.

Hernández, Marta. El Aparato Cinematográfico Español. Madrid: Akal, 1976.

Hernández, Marta. "Cine contra realidad." En Los mecanismos comunicativos del cine de todos los días, 48-57. Santander: Shangrila, 2016.
Jakobson, Roman. "¿Decadencia del cine?" En Contribuciones al análisis semiológico del film, 171-182. Valencia: Fernando Torres Editor, 1976.

Léon, Pierre. "L'Espagne-temps. Contactos de Paulino Viota." Trafic 91 (Otoño 2014): 66-70.

Llinás, Francisco. "Contactos de Paulino Viota." Nuestro Cine 106 (Febrero 1971): 14-15.

Molina Foix, Vicente. "Imagen del cine independiente español." Nuestro Cine 77-78 (Noviembre-diciembre 1968): 72-76.

Oteiza, Jorge. Quousque tandem...! PamplonaIruña: Pamiela, 1994.

Pasolini, Pier Paolo. "Discurso sobre el planosecuencia, o el cine como semiología de la realidad." En Ideología y lenguaje cinematográfico, 53-68. Madrid: Alberto Corazón Editor, 1969.

Pena, Jaime. "Contactos." En Antología crítica del cine español 1906-1995, 677-679. Madrid: Cátedra, 1997.

Ruiz, Raúl. Poéticas del cine. Santiago de Chile: Ediciones Universidad Diego Portales, 2013.

Vega, Javier, Santos Zunzunegui, y Paulino Viota. "Contactos. Guión original." En Paulino Viota. El orden del laberinto, editado por Rubén García López, 335-392. Santander: Shangrila, 2015.

Viota, Paulino. "Carta sobre Contactos." Vértigo 13-14 (Noviembre 1998): 108-113.

Zedong, Mao. "Sobre la contradicción." En Obras escogidas, tomo I, 333-369. Pekín: Ediciones en Lenguas Extranjeras, 1976.

Zunzunegui, Santos. "Prólogo." En El tragaluz del infinito, 7-13. Madrid: Cátedra, 2006. 
